\title{
Monitoring of Fluoride Concentration in Groundwater of Tosham Block, Bhiwani District, NW, India: Correlation with Physico-Chemical Parameters
}

\author{
Savita Kumari*, Naresh Kumar, Naresh Kochhar, Renu Daulta \\ Department of Geology, Krukshetra University, Kurukshetra, India \\ Email: ^Savi_geokuk@yahoo.com, renu.verma71@gmail.com
}

How to cite this paper: Kumari, S., Kumar, N., Kochhar, N. and Daulta, R. (2020) Monitoring of Fluoride Concentration in Groundwater of Tosham Block, Bhiwani District, NW, India: Correlation with Physico-Chemical Parameters. Open Journal of Geology, 10, 1047-1058.

https://doi.org/10.4236/ojg.2020.1011050

Received: September 7, 2020

Accepted: November 7, 2020

Published: November 10, 2020

Copyright $\odot 2020$ by author(s) and Scientific Research Publishing Inc. This work is licensed under the Creative Commons Attribution International License (CC BY 4.0).

http://creativecommons.org/licenses/by/4.0/ Open Access

\begin{abstract}
Hydrogeochemical investigations were carried out in the eight villages of Tosham Block; district Bhiwani, Haryana to recognize the mechanism and sources of enrichment of fluoride in the groundwater. The results specify that concentrations of fluoride attain up to $1.9 \mathrm{mg} / \mathrm{l}$ in groundwater samples. In the soils, the overall fluorine contents vary between 1.1 and $2.7 \mathrm{mg} / \mathrm{kg}$, which could have sufficient potential to released fluorine into the groundwater. In groundwater, the fluoride enrichment is primarily controlled by solubility of fluorite, intensity of evapotranspiration, residence time and the processes of weathering prevailing in Tosham area. Moreover, various other water quality parameters such as $\mathrm{pH}$, electrical conductivity, total hardness, and total alkalinity as well as calcium, magnesium, carbonate, bicarbonate and chloride concentrations were also calculated. A logical calculation of correlation coefficients between different physico-chemical parameters was done. The $67 \%$ of groundwater samples do not comply with WHO standards of fluoride for drinking purposes. The excessive fluoride concentration in the groundwater of villages under study causes dental fluorosis among people especially the children. Except few of villages, without any prior treatment, the overall quality of water was found unacceptable for drinking purposes.
\end{abstract}

\section{Keywords}

Fluoride, Fluorosis, Groundwater, Hydrochemistry, Tosham

\section{Introduction}

An adequate supply of safe water for household consumption is one of the ut- 
most challenges of the twenty-first century. Constantly, the demand for water is on rise. The water resources are unevenly distributed over the earth's surface. Moreover, the excellence of the water resources, which are disproportionately scattered over the surface of earth, is fading due to the anthropogenic and natural activities. In the near future, the countries even having gigantic water resources could experience water scarcity. The properties of groundwater have also been changing simultaneously corresponding to heavy use of fertilizers, dumping of industrial and municipal waste. Hence, to study the variation in quality parameters, the analysis of groundwater is essential. The groundwater quality could be rated for various uses, like industrial, drinking agriculture on the basis of the physico-chemical parameters. The groundwater pollution also governed by the geology of the area where widespread cavern systems are beneath the water table [1]. The changes in groundwater quality respond to the deviation in chemical, physical, and genetic environments through which it passes [2]. Fluoride with an optimum concentration within a narrow range between toxic exposure and beneficial ingestion is essential for human beings [3] [4] [5]. Due to long term intake of waterborne fluoride over the permissible limit of $1.5 \mathrm{mg} / \mathrm{l} \mathrm{set}$ by the World Health Organization (WHO) and $1.0 \mathrm{mg} / \mathrm{l}$ by China, endemic fluorosis has been extensively reported in numerous areas such as Mexico, China, India and Africa [6]-[12]. The low concentrations of $\mathrm{Ca}^{2+}$, cation exchange, high $\mathrm{pH}$, sometimes high concentrations of $\mathrm{Na}^{+}$and $\mathrm{HCO}_{3}^{-}$, evapotranspiration, hydrolysis of silicate minerals are the most common factors behind the fluoride enrichment in groundwater [13]. The correlation between fluoride and other physical parameters has done in this study. A positive correlation coefficient of sodium with fluoride in ground water has reported in groundwater samples of study area. In the present investigation, the analysis of ground water samples of eight villages of Tosham block of Bhiwani District is presented. The correlation analysis of the physicochemical parameters, $\mathrm{pH}, \mathrm{EC}, \mathrm{TH}, \mathrm{Na}^{+}, \mathrm{Ca}^{2+}, \mathrm{Mg}^{2+}, \mathrm{Cl}^{-}$, $\mathrm{CO}_{3}^{2-}, \mathrm{F}^{-}$and $\mathrm{HCO}_{3}^{-}$measured in 19 samples collected from eight villages. The results obtained are presented and discussed in this paper. The purpose of this study is to elucidate the fluoride distribution in area under study and to establish a correlation between fluoride concentration and physico-chemical parameters of groundwater of Tosham block, Bhiwani district, NW, India. The present paper also tries to find the role of local geology in fluoride contamination in area under study.

\section{Geology Setting of the Study Area}

Malani Igneous Suite (MIS) representatives are well exposed in the Bhiwani district (at Tosham area) of Haryana, Jodhpur, Jhunjhunu, Barmer, Pali, (at Siwana, Kundal and Nakora areas) Jaisalmer Jalor, districts of Rajasthan and are also reported from Nagar Parkar, Kirana hills (Pakistan). Tosham Ring Complex (Survey of India topography sheet No. 44P/13; Scale $1: 50,000) ;\left(28^{\circ} 46^{\prime} \mathrm{N}-28^{\circ} 55^{\prime} \mathrm{N}\right.$; $75^{\circ} 50^{\prime} \mathrm{E}-75^{\circ} 58^{\prime} \mathrm{E}$ ) is located $160 \mathrm{KM}$ WNW of Delhi which is a part of Malani 
Igneous Suite. Malani Igneous Suite (MIS) is one of the most important alkaline anorogenicmagmatism in the Indian subcontinent which represents the Pan-African thermotectonic episode [14]. Tosham is a town situated on the foot of Tosham hill range in district Bhiwani, Haryana. As of 2011 India census, Tosham had a population of 11,271 . Females constitute $47 \%$ and $53 \%$ of the population are males. There is a well-known temple of Mugipa and are numerous holy ponds on Tosham Hill inside the caves, namely Surya Kund, Pandu TeerthKund, Kukkar, VyasKund, A small tank like reservoir also found on the summit of the hill to conserve rain water. The geology of Tosham is described by many researchers [15] [16]. The main rock types of Tosham are granites (hypersolvus and subsolvus), rhyolites, dacites, trachytes, andesites, basalts, gabbros and dolerites. They occur in the form of ring dykes, ring structures, scattered hummocks, inselbergs and residual hills where the exposures are covered by sand dunes. Granites from Tosham and adjoining areas are generally pink, grey and green color and medium grained leucocratic with biotite or hornblende granites. Quartzite is also noticed at some locality. Granites exposed at Khanak, Nigana, Dulheri, Riwasa and Nigana are leucocratic to melanocratic, medium to coarse grained and porphyritic nature. Granitoids from Khanak are grey to pinkish with medium to coarse grained nature. They are composed of quartz, alkali feldspar, plagioclase and biotite. Granite porphyry and quartz porphyry from Khanak occur in pockets and are reported to be of marginal phase of differentiation [17].

\section{Sampling and Analytical Methods}

Nineteen groundwater and nineteen soil samples were collected from eight villages of Tosham area (Figure 1). All of the groundwater samples were collected from boreholes and dugwellsafter filtration through $0.45 \mu \mathrm{m}$ PVDF branes (Millipore) and sealed on the spot. Samples for the determination of major cations $\left(\mathrm{Na}^{+}, \mathrm{Ca}^{2+}, \mathrm{Mg}^{2+}\right.$ and $\left.\mathrm{K}^{+}\right)$were stock up in polyethylene bottles that had been soaked in $5 \% \mathrm{HCl}$ and before collection three times rinsed by distilled water. Then, $1 \%(\mathrm{v} / \mathrm{v})$ concentrated redistilled $\mathrm{HNO}_{3}$ was added to stabilize the samples to $\mathrm{pH}<2$. Samples for major anions $\left(\mathrm{Cl}^{-}, \mathrm{F}^{-}, \mathrm{NO}_{3}^{-}\right.$, and $\left.\mathrm{SO}_{4}^{2-}\right)$ were stored in polyethylene bottles without chemical agents added. Major elements and trace elements were analyzed within 2 weeks after sampling. Eh, $\mathrm{pH}$, temperature, and EC (electrical conductance) were measured in situ during sampling and alkalinity $\left(\mathrm{HCO}_{3}^{-}\right)$by Gran titration on site. To minimize the contact of sample with air, the unfiltered sample water was used to measure $\mathrm{pH}$ and Eh. The concentrations of most trace elements and major ions were determined by inductively coupled plasma emission. The ion chromatography is used for determination of major anions. The titration was employed to measured alkalinity. Most measurements exhibited errors of approximately $5 \%$ or less. All samples were measured at the Central Soil Salinity Research Institute, Karnal. The soil samples were

collected surface soil from 25 to $50 \mathrm{~cm}$ at Villages of Tosham which were 


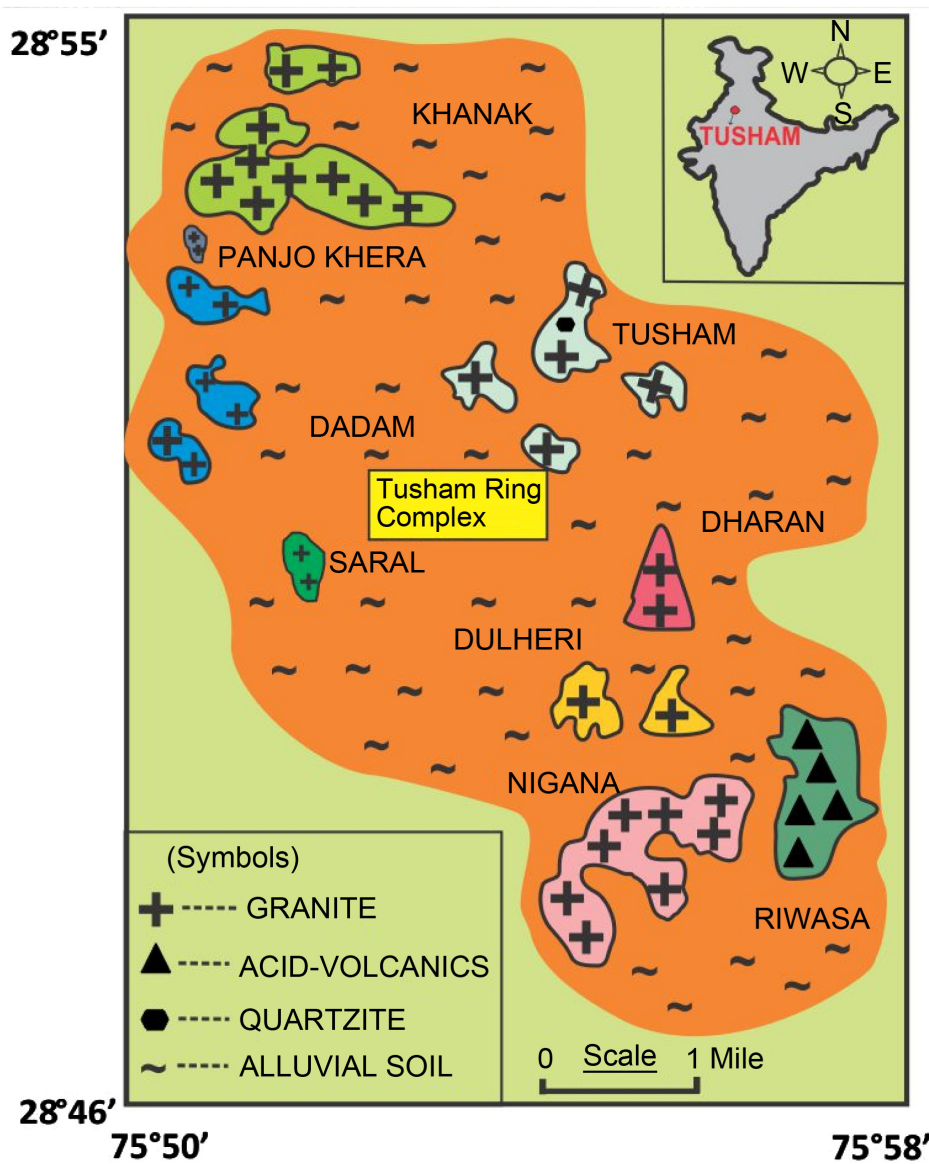

Figure 1. Soil and groundwater sampling locations.

air-dried without the sunlight in naturally. The water soluble fluoride and total fluoride contents of soil samples were tested.

\section{Results}

The result of analysis of physico-chemical parameter and fluoride in groundwater is summarized in Table 1 . The desirable limit and permissible limit of fluoride (in the absence of an alternate source), as per WHO Standard are $1.0 \mathrm{mg} / \mathrm{l}$ and $1.5 \mathrm{mg} / \mathrm{l}$ respectively. It results in fluorosis sickness if exceeding $1.5 \mathrm{mg} / \mathrm{l} . \mathrm{In}$ the present analysis, fluoride concentration varies in range of 0 to $1.9 \mathrm{mg} / \mathrm{l}$ (Table 1). The highest concentration of fluoride is shown by groundwater sample of Panjokhera village. Out of all samples, $67 \%$ of samples are found within prescribed desirable limit. The $17 \%$ of samples cross the permissible limits and remaining $16 \%$ sample have fluoride concentration higher than desirable but within the permissible limits (Figure 2). The concentration of fluoride in soil samples of eight villages are shown in Figure 3. The positive correlation between fluoride concentration of soil $(\mathrm{F}(\mathrm{s}))$ and groundwater samples $(\mathrm{F}(\mathrm{w}))$ is exhibited by Figure 4 . The most of samples peak overlapping each other establishing that both soil as well as the groundwater sample show the similar trend of variation of fluoride concentration. The concentration of fluoride in water is directly 
Table 1. Result of groundwater analysis (all values are in mg/l except $\mathrm{pH}$ and EC).

\begin{tabular}{|c|c|c|c|c|c|c|c|c|c|c|c|c|}
\hline VILLAGES & $\mathrm{pH}$ & EC & TDS & $\mathrm{Na}$ & $\mathrm{Cl}$ & K & $\mathrm{Ca}$ & $\mathrm{Mg}$ & $\mathrm{NO}_{3}$ & $\mathrm{CO}_{3}$ & $\mathrm{HCO}_{3}$ & $\mathrm{~F}$ \\
\hline KHANAK & 7.0 & $24,400.0$ & $15,616.0$ & 4548.0 & 6948.2 & 24.06 & 1442.88 & 206.55 & 0 & 0 & 1855.01 & 1.6 \\
\hline KHANAK & 7.5 & 4400.0 & 2816.0 & 309.9 & 1290.4 & 17.14 & 1042.08 & 230.85 & 0 & 0 & 512.57 & 0.0 \\
\hline DADAM & 7.9 & 1300.0 & 832.0 & 113.0 & 241.1 & 0.50 & 641.28 & 170.1 & 0 & 0 & 268.49 & 0.0 \\
\hline DADAM & 8.0 & 2180.0 & 1395.2 & 267.9 & 482.1 & 0.80 & 340.68 & 72.9 & 0 & 0 & 488.16 & 0.0 \\
\hline PANJOKHERA & 8.0 & 1670.0 & 1068.8 & 327.9 & 205.6 & 0.10 & 240.48 & 24.3 & 0 & 0 & 634.61 & 1.9 \\
\hline PANJOKHERA & 8.2 & 2000.0 & 1280.0 & 419.8 & 531.8 & 0.40 & 320.64 & 72.9 & 0 & 0 & 329.51 & 1.1 \\
\hline SARAL & 8.0 & 1544.0 & 988.2 & 218.9 & 368.7 & 6.22 & 380.76 & 109.35 & 0 & 0 & 183.06 & 1.4 \\
\hline SARAL & 7.2 & 950.0 & 610.6 & 174.9 & 205.6 & 2.41 & 240.48 & 24.3 & 1.3 & 0 & 732.24 & 0.0 \\
\hline TOSHAM & 8.0 & 1931.0 & 1235.8 & 424.8 & 312.0 & 2.71 & 280.56 & 60.75 & 0 & 0 & 305.10 & 0.7 \\
\hline TOSHAM & 8.6 & 3170.0 & 2028.8 & 549.8 & 879.2 & 5.41 & 240.48 & 48.6 & 0 & 24 & 366.12 & 0.0 \\
\hline DULHERI & 7.8 & 5000.0 & 3200.0 & 839.6 & 1446.4 & 2.71 & 1382.76 & 218.7 & 0 & 0 & 305.10 & 0.0 \\
\hline DULHERI & 7.9 & 1017.0 & 650.9 & 185.9 & 156.0 & 0.20 & 220.44 & 36.45 & 0 & 0 & 2684.88 & 0.3 \\
\hline NIGANA & 7.6 & $10,580.0$ & 6771.2 & 1809.2 & 2141.2 & 5.81 & 681.36 & 85.05 & 0 & 0 & 414.94 & 0.6 \\
\hline NIGANA & 7.5 & 3520.0 & 2252.8 & 489.8 & 950.1 & 0.80 & 460.92 & 109.35 & 0 & 0 & 329.51 & 0.4 \\
\hline RIWASA & 7.8 & 1271.0 & 813.4 & 219.9 & 255.2 & 2.61 & 260.52 & 72.9 & 0 & 0 & 427.14 & 0.6 \\
\hline RIWASA & 8.0 & 2630.0 & 1683.2 & 475.8 & 694.8 & 2.81 & 240.48 & 60.75 & 0 & 0 & 231.88 & 1.8 \\
\hline DHARAN & 8.6 & 896.0 & 573.4 & 183.9 & 184.3 & 0.20 & 180.36 & 36.45 & 0 & 24 & 219.67 & 1.4 \\
\hline DHARAN & 8.1 & 742.0 & 474.9 & 144.9 & 129.3 & 0.80 & 140.28 & 12.15 & 0 & 0 & 244.08 & 0.9 \\
\hline PWD GUEST & 6.9 & 2130.0 & 1363.2 & 150.9 & 553.0 & 10.93 & 460.92 & 97.2 & 5.1 & 0 & 244.08 & 0.7 \\
\hline
\end{tabular}

proportional to concentration of fluoride in soil and thus establishing positive correlation. Khanak and Panjokhera are two villages that have highest concentration of fluoride both in soil and groundwater samples. Twenty percent of fluoride affected villages in the world are in India [18].

Although fluoride is essential for formation of dental enamel and normal mineralization of bones and is one of the important life elements to individual health with presence in small amount, however at a higher concentration might cause detrimental effects on individual health. The largest contributor to the daily intake of fluoride is drinking water. The food when derived from plants grown in the contaminated soil also becomes another source of fluoride intake when they are used as food. The prolonged experience to elevated concentration of fluoride is poisonous to bones, teeth and other organs. If present in high concentration in drinking water, it is also known to cause thyroid [19], neurological, kidney changes, gastrointestinal and endocrine problems. In its harsh form, dental fluorosis is characterized by yellowish brown to black stains, severe pitting and opaque areas on the tooth surface. It has been estimated that $20 \%$ of those who bear osteoporosis linked hip fractures die within six months. In comparison to males, females are at four times greater threat of osteoporosis. In bottle fed infants, intake higher than $50 \mathrm{mg} / \mathrm{l}$ are identified to have been linked with 


\section{FLOURIDE}

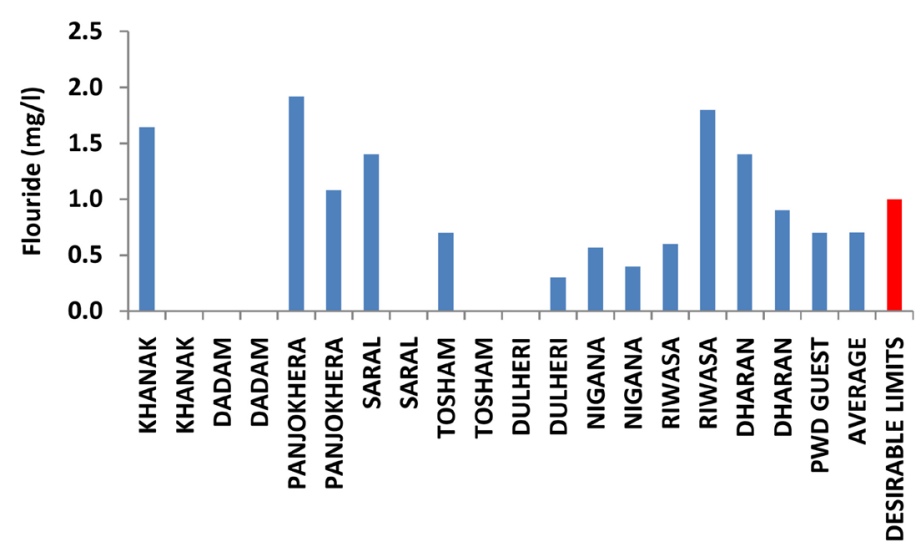

Sampling locations

Figure 2. Flouride distribution in groundwater samples of Tosham area.

\section{FLOURIDE}

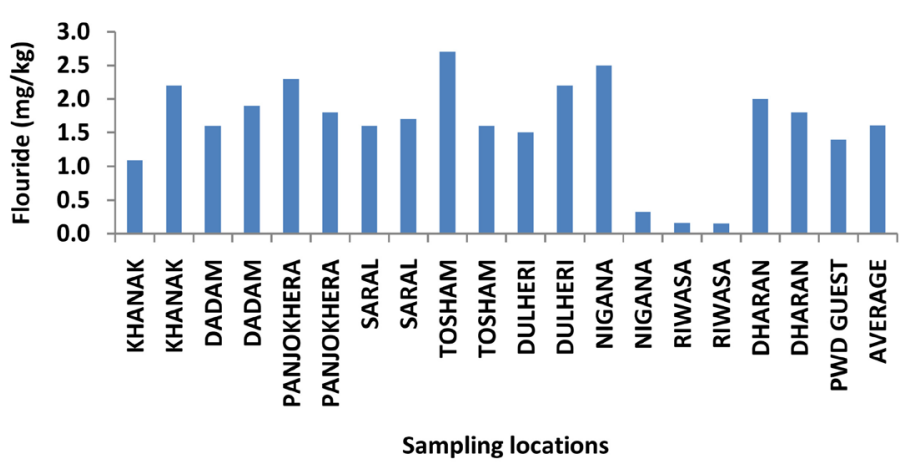

Figure 3. Fluoride distribution in soil samples of Tosham area.

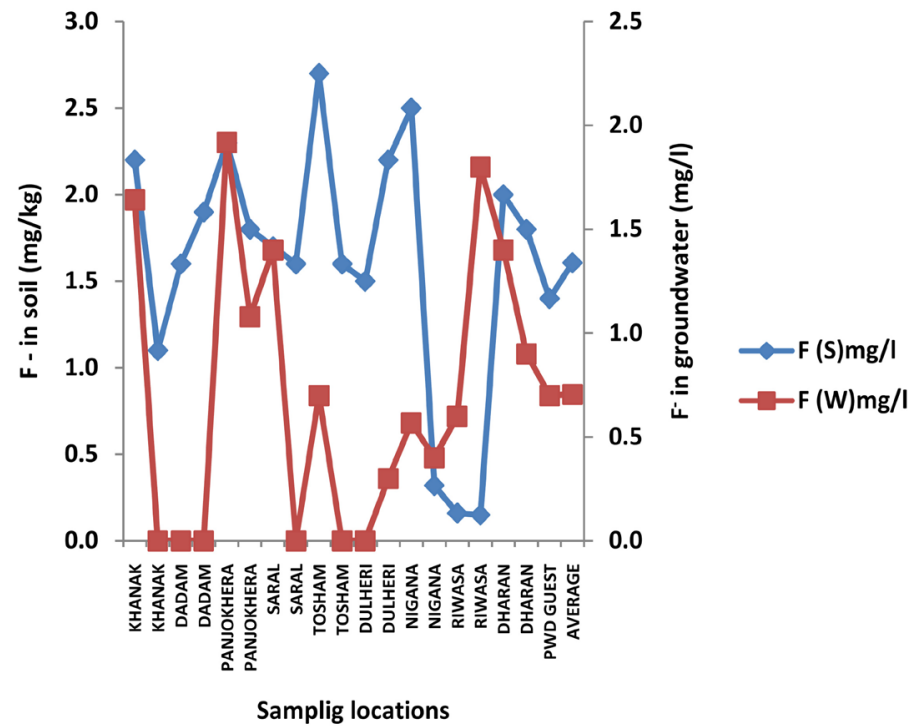

Figure 4. Positive correlation of fluoride distribution in soil and groundwater samples of Tosham area. 
methaemoglobinaemia. The fluoride concentration and associated risk are given in Table 2.

\section{Discussion}

\section{Geochemical Processes Influencing Fluoride Concentrations}

The key hydrochemical types are $\mathrm{Na}-\mathrm{Cland} \mathrm{Ca}-\mathrm{HCO}_{3}$ in the area under study. The groundwater samples having high concentration of TDS belong to $\mathrm{Na}-\mathrm{Mg}-\mathrm{HCO}_{3}-\mathrm{SO}_{4}$ and Na-Mg-Cltypes, possibly due to dissolution [20]. Thus the variation in chemistry of groundwater advocate that in the host rocks of the TRC, there are tough geochemical reactions that occur, where hydrolysis reactions of silicate playing a leading role, e.g.,

$$
\begin{gathered}
2 \mathrm{CaAl}_{2} \mathrm{Si}_{2} \mathrm{O}_{8}+6 \mathrm{H}_{2} \mathrm{O}=\mathrm{Al}_{4} \mathrm{Si}_{10} \mathrm{O}_{10}(\mathrm{OH})_{8}+2 \mathrm{Ca}^{2+}+4(\mathrm{OH})^{-} \\
2 \mathrm{NaAlSi}_{3} \mathrm{O}_{8}+2 \mathrm{H}_{2} \mathrm{CO}_{3}+9 \mathrm{H}_{2} \mathrm{O}=\mathrm{Al}_{2} \mathrm{Si}_{2} \mathrm{O}_{5}(\mathrm{OH})_{4}+2 \mathrm{Na}^{+}+2 \mathrm{HCO}_{3}^{-}+4 \mathrm{H}_{2} \mathrm{SiO}_{4}^{2-}
\end{gathered}
$$

During the processes of weathering, dissolution, hydrolysis and dissociation could take place at the same time. Kaolinite, calcite, plagioclase, K-feldspar, albite and silicate in these practices consume a huge amount of protons. That is perhaps why some groundwater samples exhibit high $\mathrm{HCO}_{3}^{-}$and $\mathrm{pH}$ values. Due to the release of $\mathrm{Na}^{+}$and $\mathrm{Ca}^{2+}$, the groundwater in the area under study is altered into $\mathrm{Ca}-\mathrm{Na}-\mathrm{HCO}_{3}$ and $\mathrm{Ca}-\mathrm{HCO}_{3}$. Previous studies have indicated that even after the groundwater reaches an equilibrium state with respect to fluorite $\left(\mathrm{CaF}_{2}\right)$, the high concentration of groundwater fluoride continuously augment due to the decrease in the $\mathrm{Ca}^{2+}$ concentration by the precipitation of calcite $\left(\mathrm{CaCO}_{3}\right)$. The slightly decrease in calcium concentration facilitates the fluoride enrichment [21]. The higher concentration of fluoride in groundwater is caused by presence of fluorine bearing minerals [22]. The dissolution of $\mathrm{CaF}_{2}$, is promoted by high alkalinity, liberate fluoride into groundwater because precipitation of dolomite and calcite can diminish the $\mathrm{Ca}^{2+}$ concentration in groundwater (hydrolysis reaction) e.g.

Table 2. Fluoride concentration and its harmful effects.

\begin{tabular}{ccr}
\hline S.No & Fluoride in drinking water $(\mathrm{mg} / \mathrm{l})$ Effect & Effects \\
\hline 1 & $1 \mathrm{mg} / \mathrm{l}$ in water & Dental caries reduction \\
2 & $2 \mathrm{mg} / \mathrm{l}$ in water & Mottled enamel \\
3 & 0.002 in air & Injury to vegetation \\
4 & $50 \mathrm{mg} / \mathrm{l}$ in food or water & Change in thyroid harmone \\
5 & $20-80 \mathrm{mg} /$ day or more & Crippling skeletal fluorosis \\
6 & $8 \mathrm{mg} / \mathrm{l}$ in water & 10\% osteoporosis \\
7 & More than $125 \mathrm{mg} / 1$ & Kidney change \\
8 & $100 \mathrm{mg} / \mathrm{l}$ in water or food & Retardation in growth \\
9 & $3.1-6 \mathrm{mg} / \mathrm{l}$ in water & Osteoporosis \\
10 & $2.5-5.0 \mathrm{gm}$ in actual dose & Death \\
\hline
\end{tabular}




$$
\begin{gathered}
\mathrm{CaF}_{2}+\mathrm{Na}_{2} \mathrm{CO}_{3}=\mathrm{CaCO}_{3}+2 \mathrm{~F}^{-}+2 \mathrm{Na}^{+} \\
\mathrm{CaF}_{2}+2 \mathrm{NaHCO}_{3}=\mathrm{CaCO}_{3}+2 \mathrm{Na}^{+}+2 \mathrm{~F}^{-}+\mathrm{H}_{2} \mathrm{O}+\mathrm{CO}_{2} \\
\left.\left.\mathrm{Ca}^{2+}+2 \mathrm{Na} \text { (sorbed }\right)=2 \mathrm{Na}^{+}+\mathrm{Ca} \text { (sorbed }\right)
\end{gathered}
$$

Consequently, with groundwater flow the continuous dissolution of silicate can direct the slight increase in the $\mathrm{Na}^{+}$concentration and decrease in the $\mathrm{Ca}^{2+}$ concentration. The enrichment of $\mathrm{Na}$ in groundwater may be contributed by$\mathrm{Na}-\mathrm{Ca}$ ion exchange [23]. The clay minerals and sediments can release $\mathrm{Na}^{+}$into the groundwater and take up $\mathrm{Ca}^{2+}$ from groundwater, therefore change the value of $[\mathrm{Na}] /[\mathrm{Ca}]$. From Figure 5, we undoubtedly see that F concentration increase with the value of $[\mathrm{Na}] /[\mathrm{Ca}]$.

Dissolution of high heat producing granite and acid volcanic in TRC leads to the increase in $\mathrm{Na}^{+}$concentrations and anorthite weathering contributes to genesis of $\mathrm{Na}-\mathrm{HCO}_{3}$ type water in Tosham area. Moreover, the fluoride exhibits the positive correlation with bicarbonate and negative correlation with calcium. This can be explained on the basis of the chemical thermodynamics as shown in the following equation:

$$
\mathrm{CaCO}_{3}+\mathrm{H}^{+}=\mathrm{Ca}^{2+}+\mathrm{HCO}_{3}^{-}
$$

By applying the law of chemical equilibrium constant $\left(K_{1}\right)$ can be expressed as,

$$
K_{1}=\left[\mathrm{Ca}^{2+}\right]\left[\mathrm{HCO}_{3}^{-}\right] / \mathrm{H}^{+}
$$

Equilibrium constant $\left(K_{2}\right)$ in dissolution of $\mathrm{CaF}_{2}$ dissolved in water is given by

$$
K_{2}=\left[\mathrm{Ca}^{2+}\right]\left[\mathrm{F}^{-}\right]
$$

Using Equations (2) and (3),

$$
K_{1} / K_{2}=\left[\mathrm{HCO}_{3}^{-}\right] /\left[\mathrm{H}^{+}\right]\left[\mathrm{F}^{-}\right]
$$

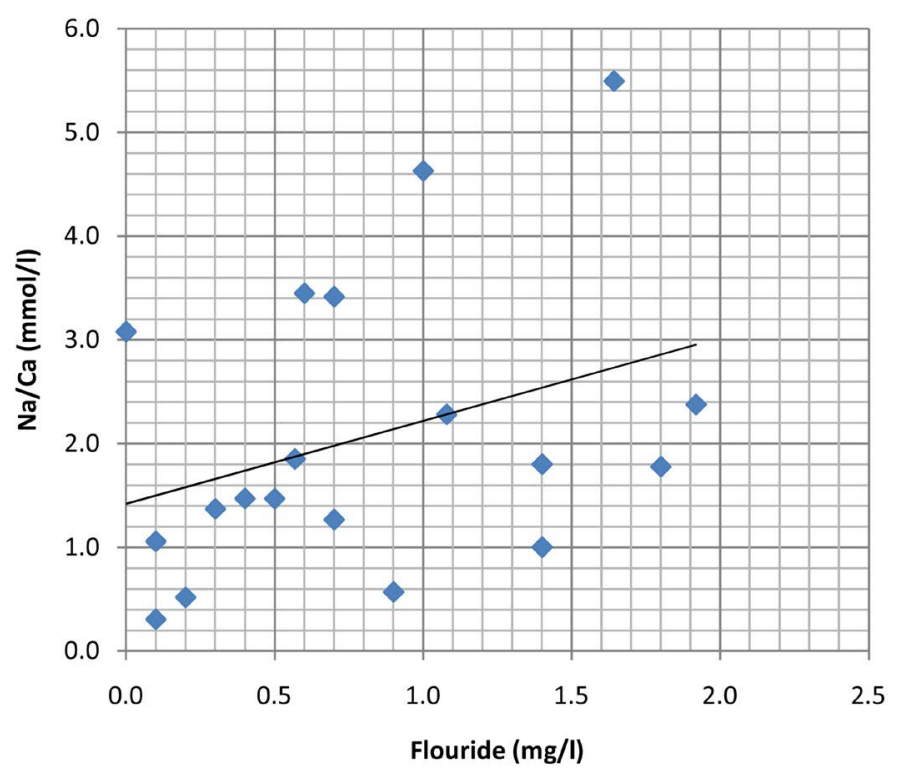

Figure 5. The plot of $\mathrm{F}^{-}$concentration vs $\mathrm{Na} / \mathrm{Ca}$. 
The Equation (4) shows the relationship between bicarbonate, hydrogen ion and fluoride and interpret that the it the $\mathrm{pH}$ (hydrogen ion activity) of water is constant an increase in fluoride ion would be accompanied increases in bicarbonate ions while in Equation (2) shows that increase in the fluoride is accompanied by corresponding decrease in calcium ions and thus shows negative correlation. The interionic relationship of $\mathrm{Fvs} \mathrm{pH}, \mathrm{Ca}^{+}, \mathrm{CO}_{3}^{2-}$ and $\mathrm{HCO}_{3}^{-}$in the groundwater samples of area under study is depicting in Figures 6-9.

\section{Conclusions}

Fluoride concentration in most of the groundwater samples of Tosham area, Bhiwani, NW, India found to be higher than BIS standards. This study reveals that the fluoride bearing minerals are the foremost sources for fluoride in

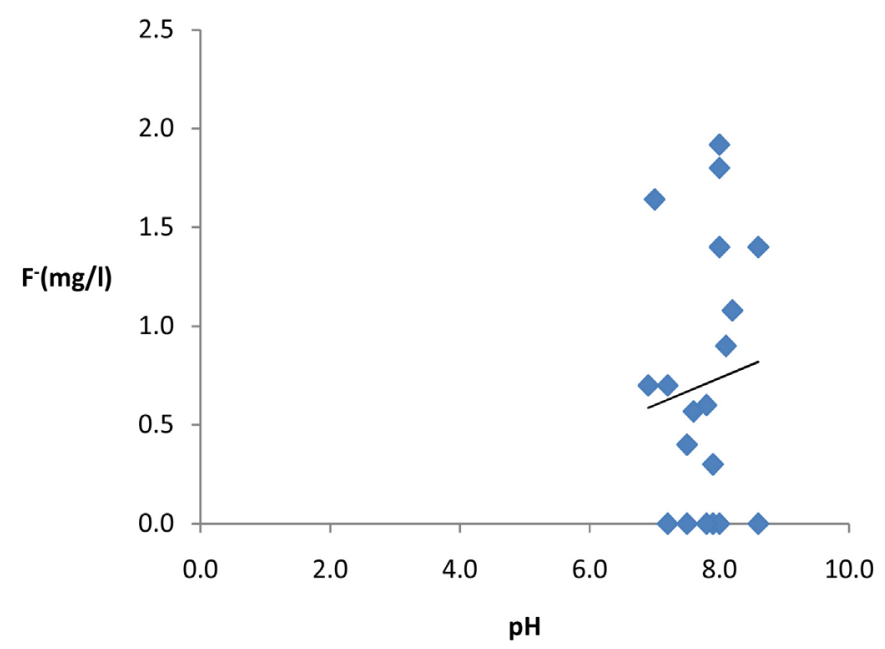

Figure 6. Scatter plot of $\mathrm{F}^{-} \mathrm{vs} \mathrm{pH}$ of groundwater samples of Tosham area.

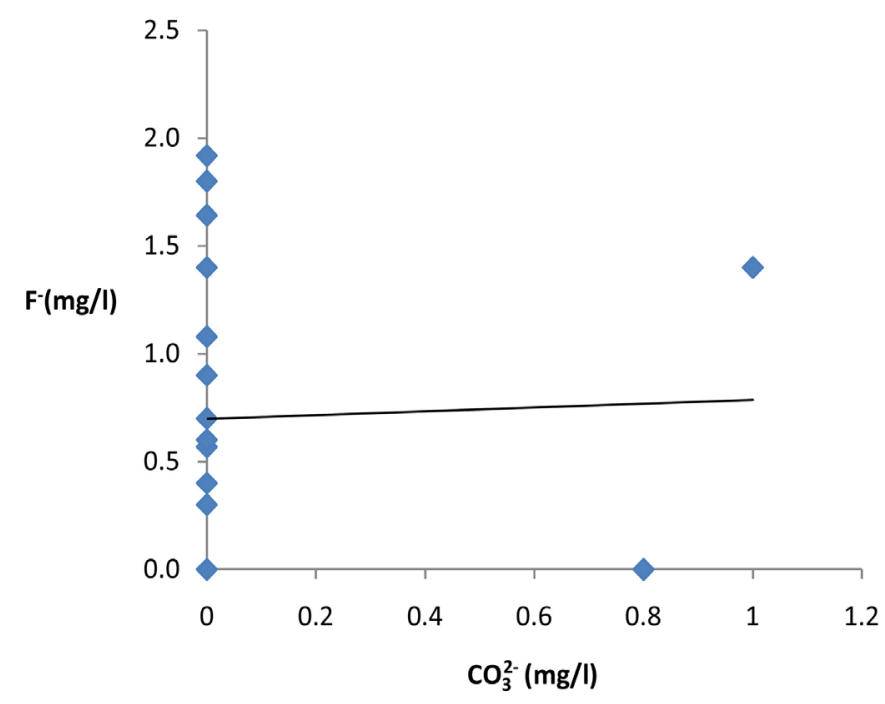

Figure 7. Scatter plot of $\mathrm{F}^{-}$vs $\mathrm{CO}_{3}^{2-}$ of groundwater samples of Tosham area. 


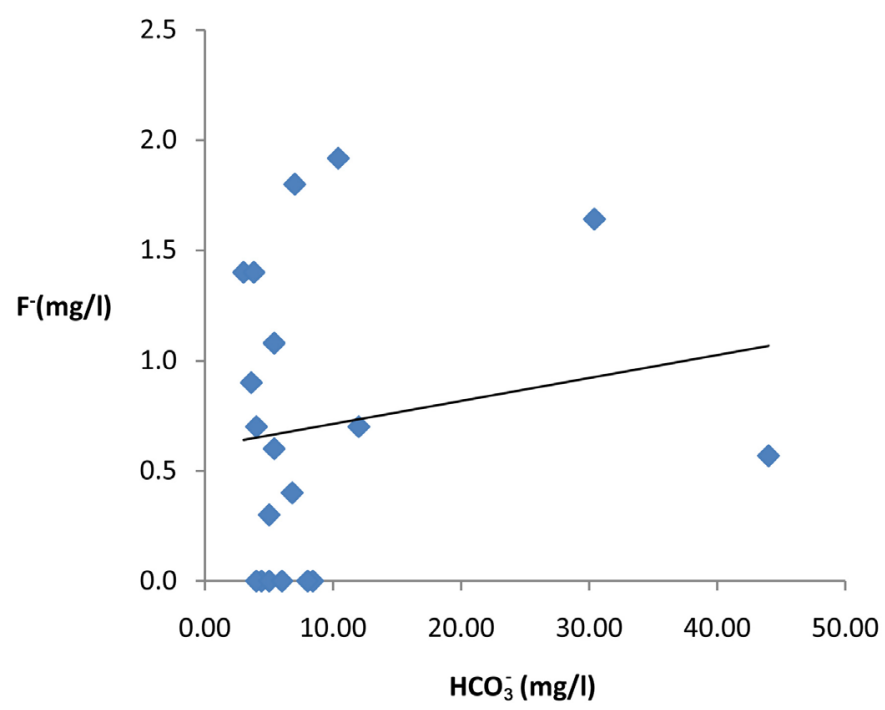

Figure 8. Scatter plot of $\mathrm{F}^{-}$vs $\mathrm{HCO}_{3}^{-}$of groundwater samples of Tosham area.

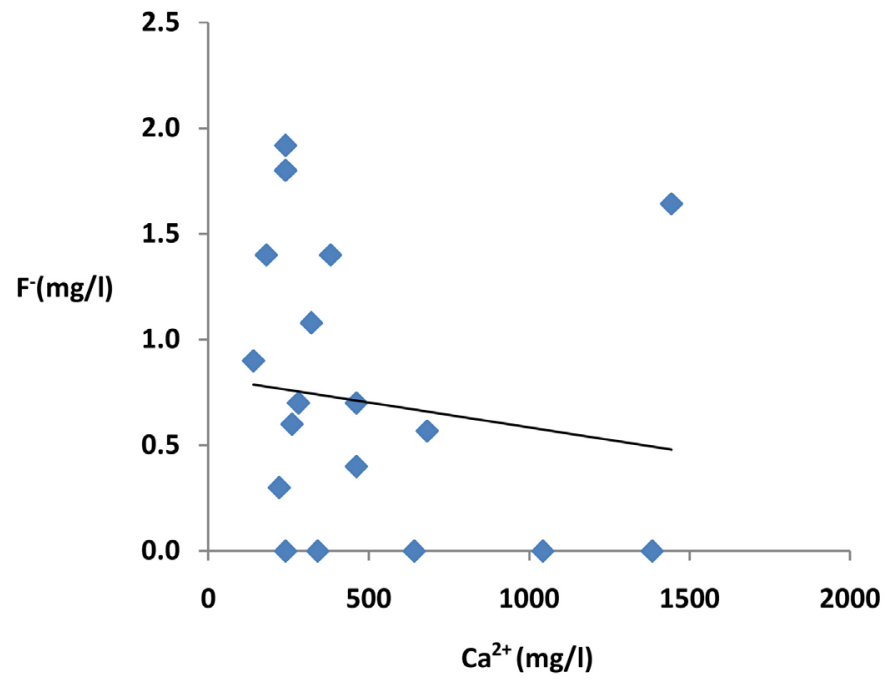

Figure 9. Scatter plot of $\mathrm{F}^{-}$vs $\mathrm{Ca}^{2+}$ of groundwater samples of Tosham area.

groundwater in villages of Tosham area. Due to removal of $\mathrm{Ca}^{2+}$ by the precipitation of calcite, the fluoride enrichment may still continue even when fluorite $\left(\mathrm{CaF}_{2}\right)$ reaches an equilibrium state. The prolonged rock-water interactions facilitate the enrichment of groundwater fluoride. Though precipitation may perhaps cause dilution effects, weathering, ion exchange, dissolution of high heat producing granites are complimentary for fluoride fortification in groundwater of area under study. Fluoride distribution is related with $\mathrm{pH}$, chloride, calcium and magnesium. In present study, the parameters like EC, $\mathrm{pH}$, chloride, Total Hardness, magnesium and calcium show the positive correlation with fluoride. Moreover, the parameters like bicarbonate, total alkalinity and carbonate exhibit the negative correlations with fluoride. 


\section{Acknowledgements}

The authors are thankful to the central soil salinity research institute, Karnal and Guru Jambheshwar University, Hisar for analyzing the water samples.

\section{Conflicts of Interest}

The authors declare no conflicts of interest regarding the publication of this paper.

\section{References}

[1] Singh, K.P. (1982) Environmental Effects of Industrialization of Groundwater Resources: A Case Study of Ludhaina Area, Punjab, India. Soil, Geology and Landform-Impact of Land Uses in Developing Countries, Bangkok, E6.1-E6.7.

[2] Singh, M., Kaur, S. and Sooch, S.S. (2003) Groundwater Pollution-An Overview. J. IPHE, 2, 29-31.

[3] Deng, Y.M., Nordstrom, D.K. and McCleskey, B.R. (2011) Fluoride Geochemistry of Thermal Waters in Yellowstone National Park: I. Aqueous Fluoride Speciation. Geochimicaet Cosmochimica Acta, 75, 4476-4489. https://doi.org/10.1016/j.gca.2011.05.028

[4] Kim, K. and Jeong, G.Y. (2005) Factors Influencing Natural Occurrence of Fluoride-Rich Groundwaters: A Case Study in the Southeastern Part of the Korean Peninsula. Chemosphere, 58, 1399-1408. https://doi.org/10.1016/j.chemosphere.2004.10.002

[5] Guo, H.M. and Wang, Y.X. (2004) Hydrogeochemical Processes in Shallow Quaternary Aquifers from the Northern Part of the Datong Basin, China. Applied Geochemistry, 19, 19-27. https://doi.org/10.1016/S0883-2927(03)00128-8

[6] Furi, W., Razack, M., Abiye, T.A., et al. (2011) Fluoride Enrichment Mechanism and Geospatial Distribution in the Volcanic Aquifers of the Middle Awash Basin, Northern Main Ethiopian Rift. Journal of African Earth Sciences, 60, 315-327. https://doi.org/10.1016/j.jafrearsci.2011.03.004

[7] Guo, Q.H., Wang, Y.X., Ma, T., et al. (2007) Geochemical Processes Controlling the Elevated Fluoride Concentrations in Groundwaters of the Taiyuan Basin, Northern China. Journal of Geochemical Exploration, 93, 1-12. https://doi.org/10.1016/j.gexplo.2006.07.001

[8] Zhu, C.S., Bai, G.L., Liu, X.L., et al. (2006) Screening High-Fluoride and High-Arsenic Drinking Waters and Surveying Endemic Fluorosis and Arsenism in Shanxi Province in Western China. Water Research, 40, 3015-3022. https://doi.org/10.1016/j.watres.2006.06.026

[9] Saxena, V. and Ahmed, S. (2001) Dissolution of Fluoride in Groundwater: A Water-Rock Interaction Study. Environmental Geology, 40, 1084-1087.

https://doi.org/10.1007/s002540100290

[10] Wang, L.F. and Huang, J.Z. (1995) Outline of Control Practice of Endemic Fluorosis in China. Social Science and Medicine, 41, 1191-1195. https://doi.org/10.1016/0277-9536(94)00429-W

[11] Delrazo, L.M., Corona, J.C., Garciavargas, G., et al. (1993) Fluoride Levels in Well-Water from a Chronic Arsenicism Area of Northern Mexico. Environmental Pollution, 80, 91-94. https://doi.org/10.1016/0269-7491(93)90015-G

[12] McInnes, P.M., Richardson, B.D. and Cleatonjones, P.E. (1982) Comparison of 
Dental Fluorosis and Caries in Primary Teeth of Preschool-Children Living in Reid High and Low Fluoride Villages. Community Dentistry and Oral Epidemiology, 10, 182-186. https://doi.org/10.1111/j.1600-0528.1982.tb00376.x

[13] Abu Rukah, Y. and Alsokhny, K. (2004) Geochemical Assessment of Groundwater Contamination with Special Emphasis on Fluoride Concentration, North Jordan. Chemie Der Erde-Geochemistry, 64, 171-181. https://doi.org/10.1016/j.chemer.2003.11.003

[14] Kochhar, N. (1982) Copper Mineralization in Tusham Area, Bhiwani District, Haryana, Rejoinder. Indian Minerals, 36, 50-51.

[15] Kumar, N. and Vallinayagam, G. (2010) Primary Volcanic Structures from Nakora Area of Malani Igneous Suite, Western Rajasthan: Implications for Cooling and Emplacement of Volcanic Flows. Current Science, 98, 550-557.

[16] Kumar, N. and Vallinayagam, G. (2012) Geochemistry and Petrogenesis of Neoproterozoic A-Type Granites at Nakora in the Malani Igneous Suite, Western Rajasthan, India. Chinese Journal of Geochemistry, 31, 221-233. https://doi.org/10.1007/s11631-012-0571-5

[17] Meenakshi and Maheshwari, R.C. (2006) Fluoride in Drinking Water and Its Removal. Journal Hazardous Matter, 137, 456-463.

https://doi.org/10.1016/j.jhazmat.2006.02.024

[18] Hussain, I., Arif, M. and Hussain, J. (2011) Fluoride Contamination in Drinking Water in Rural Habitations of Central Rajasthan, India. Environmental Monitoring and Assessment, 184, 5151-5158. https://doi.org/10.1007/s10661-011-2329-7

[19] Jacks, G., Bhattacharya, P., Chaudhary, V., et al. (2005) Controls on the Genesis of Some High-Fluoride Groundwaters in India. Applied Geochemistry, 20, 221-228. https://doi.org/10.1016/j.apgeochem.2004.07.002

[20] World Health Organization (1998) Guidelines for Drinking-Water Quality. 2nd Edition, WHO, Geneva.

[21] Turner, B.D., Binning, P. and Stipp, S.L.S. (2005) Fluoride Removal by Calcite: Evidence for Fluorite Precipitation and Surface Adsorption. Environmental Science and Technology, 39, 9561-9568. https://doi.org/10.1021/es0505090

[22] Reddy, D.V., Nagabhushanam, P., Sukhija, B.S., et al. (2010) Fluoride Dynamics in the Granitic Aquifer of the Wailapally Watershed, Nalgonda District, India. Chemical Geology, 269, 278-289. https://doi.org/10.1016/j.chemgeo.2009.10.003

[23] Wang, Y.X., Shvartsev, S.L. and Su, C. (2009) Genesis of Arsenic/Fluoride-Enriched Soda Water: A Case Study at Datong, Northern China. Applied Geochemistry, 24, 641-649. https://doi.org/10.1016/j.apgeochem.2008.12.015 